\title{
Reservoir and sealing properties of the Newark rift basin formations: Implications for carbon sequestration
}

\author{
N. V. Zakharova ${ }^{1,2}$, D. S. Goldberg'2, P. E. Olsen², D. Collins ${ }^{3}$, and D. V. Kent ${ }^{2,4}$
}

https://doi.org/10.1190/tle39010038.1

\section{Abstract}

The Newark Basin is one of the major Mesozoic rift basins along the U.S. Atlantic coast evaluated for carbon dioxide $\left(\mathrm{CO}_{2}\right)$ storage potential. Its geologic setting offers an opportunity to assess both the traditional reservoir targets, e.g., fluvial sandstones, and less traditional options for $\mathrm{CO}_{2}$ storage, e.g., mafic intrusions and lavas. Select samples from the basal, predominantly fluvial, Stockton Formation are characterized by relatively high porosity $(8 \%-18 \%)$ and air permeability $(0.1-50 \mathrm{mD})$, but borehole hydraulic tests suggest negligible transmissivity even in the high-porosity intervals, emphasizing the importance of scale in evaluating reservoir properties of heterogeneous formations. A stratigraphic hole drilled by TriCarb Consortium for Carbon Sequestration in the northern basin also intersected numerous sandstone layers in the predominantly lacustrine Passaic Formation, characterized by core porosity and permeability up to $18 \%$ and $2000 \mathrm{mD}$. However, those layers are shallow (predominantly above $1 \mathrm{~km}$ in this part of the basin) and lack prominent caprock layers above. The mudstones in all three of the major sedimentary formations (Stockton, Lockatong, and Passaic) are characterized by a high $\mathrm{CO}_{2}$ sealing capacity - evaluated critical $\mathrm{CO}_{2}$ column heights exceed several kilometers. The igneous options are represented by basalt lavas, with porous flow tops and massive flow interiors, and a crystalline but often densely fractured Palisade Sill. The Newark Basin basalts may be too shallow for sequestration over most of the basin's area, but many other basalt flows exist in similar rift basins. Abundant fractures in sedimentary and igneous rocks are predominantly closed and/or sealed by mineralization, but stress indicators suggest high horizontal compressional stresses and strong potential for reactivation. Overall, the basin potential for $\mathrm{CO}_{2}$ storage appears low, but select formation properties are promising and could be investigated in the Newark Basin or other Mesozoic rift basins with similar fill but a different structural architecture.

\section{Introduction}

As anthropogenic emissions of carbon dioxide $\left(\mathrm{CO}_{2}\right)$ continue to grow, the need to mitigate their negative effects on Earth's climate becomes more and more pressing. Most energy technology evaluations agree that carbon capture, utilization, and storage should be part of a global solution for $\mathrm{CO}_{2}$ emission reduction (e.g., IEA, 2018; IPCC, 2018). A diverse portfolio of potential sites for geologic $\mathrm{CO}_{2}$ storage is needed to achieve the necessary storage volumes and efficiency and to reduce operational costs (e.g., Aydin et al., 2010; Levine et al., 2016; Rodosta et al., 2017). Here, we report the results of evaluating reservoir and sealing properties of the Mesozoic Newark rift basin, located in the northeastern United States. The site lies in close proximity to many $\mathrm{CO}_{2}$ sources, such as large industrial plants, oil refineries, and fossil-fuel-based electric generating facilities in New York, New Jersey, and Pennsylvania (Figure 1). The Newark Basin is one of the largest exposed rift basins along the U.S. Atlantic coast, which were formed during the breakup of Pangaea in Late Triassic-Early Jurassic (Olsen et al., 1989; Withjack et al., 2013). The basin fill consists of fluvial and lacustrine sedimentary rocks and intrusive and extrusive basaltic rocks belonging to the Central Atlantic magmatic province (CAMP) (Figure 1). This geologic setting offers an opportunity to evaluate both the conventional sedimentary features, such as basal fluvial sandstones, and more exploratory options for $\mathrm{CO}_{2}$ storage, such as basic igneous rocks. The latter are highly reactive with $\mathrm{CO}_{2}$ and could help to permanently sequester anthropogenic $\mathrm{CO}_{2}$ through carbonation (e.g., McGrail et al., 2016; Pogge von Strandmann et al., 2019).

Material presented in this paper draws on multiple projects conducted in the Newark Basin over more than 20 years of research and aims at synthesizing results relevant to evaluating the $\mathrm{CO}_{2}$ storage potential of the Newark Basin formations. One of the earliest and most significant scientific drilling campaigns was the Newark Basin Coring Project (NBCP) in the 1990s, which collected more than $6700 \mathrm{~m}$ of core spanning the full stratigraphic section of the basin along with standard well logging data (Goldberg et al., 1994; Kent et al., 1995; Olsen et al., 1996). Many subsequent studies utilized this core collection, drilled from seven stratigraphically offset holes in the central part of the basin (Figure 1c). More recently, the TriCarb Consortium for Carbon Sequestration (TriCarb) collected new seismic data and drilled a deep stratigraphic hole in the northern part of the basin, with some limited coring and extensive state-of-the-art well logging, specifically for evaluating Newark Basin's $\mathrm{CO}_{2}$ storage potential (Collins, 2017) (Figure 3). A shorter core hole was also drilled in the northern part of the basin penetrating the main igneous body, the Palisade Sill, the basal sandstones, and reaching basement. The TriCarb study was followed by a narrower geomechanical study of the Newark Basin formations, and petrophysical results from this project are also incorporated in the paper. Finally, core analysis is complemented by the results of hydrogeologic tests performed in two shallow test wells on the campus of Lamont-Doherty Earth Observatory, Columbia University (Goldberg and Burgdorff, 2005; Matter et al., 2006; Zakharova et al., 2016).

${ }^{1}$ Central Michigan University, Department of Earth and Atmospheric Sciences, Mount Pleasant, Michigan, USA. E-mail: n.zakh@cmich.edu.

${ }^{2}$ Lamont-Doherty Earth Observatory, Columbia University, Palisades, New York, USA. E-mail: goldberg@1deo.columbia.edu; polsen@1deo.columbia.edu.

${ }^{3}$ Geostock Sandia LLC, Houston, Texas, USA. E-mail: dan.collins@geostocksandia.com.

${ }^{4}$ Rutgers University, Department of Earth and Planetary Sciences, Piscataway, New Jersey, USA. E-mail: dvk@1deo.columbia.edu. 
This paper is an overview of reservoir and sealing properties of the Newark Basin formations and integrates all of the analysis done by these various projects to date. This information makes it possible to draw some preliminary conclusions on the suitability of the Newark Basin for geologic $\mathrm{CO}_{2}$ storage and highlights issues that need to be addressed in the studies of Mesozoic rift basins for carbon sequestration (Table 1).

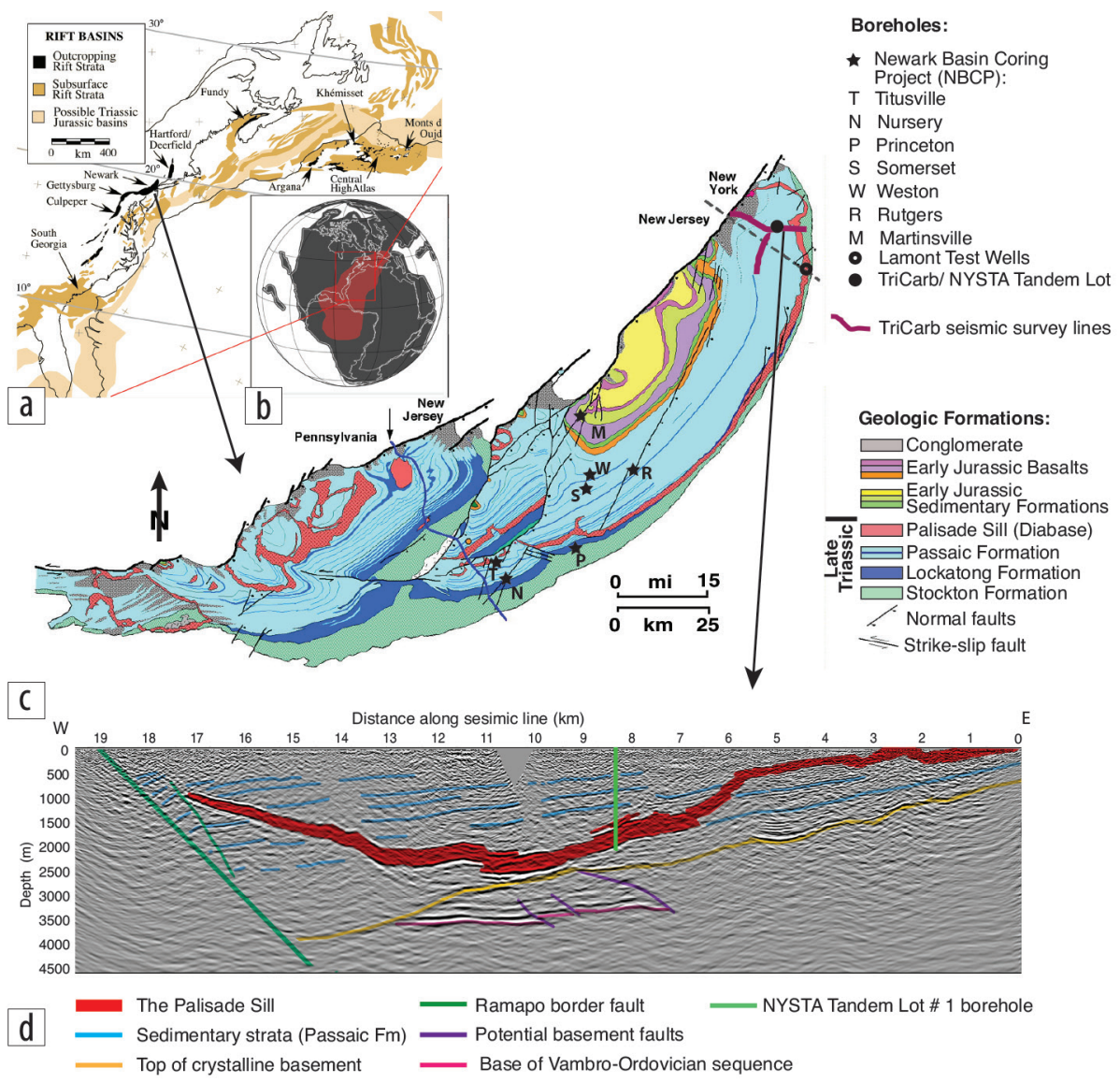

Figure 1. Geologic map and setting of the Newark rift basin. (a) Mesozoic rift system of eastern North America. (b) The extent of the rift zone and associated CAMP within the Pangaean supercontinent. (c) Geologic maps of the Newark Basin showing major formations and boreholes discussed in the paper. (d) Migrated reflection seismic profile across the northern basin acquired by TriCarb with geologic interpretation by author.

\section{Basin structure and potential $\mathrm{CO}_{2}$ storage targets}

The Newark Basin is an elongated half-graben rift basin encompassing an area of more than $7510 \mathrm{~km}^{2}$ in southeastern New York, northern New Jersey, and southeastern Pennsylvania (Figure 1). The strata generally are dipping northwest toward the border fault system at about $10^{\circ}$ from horizontal and are overlapping crystalline basement on the eastern side. Several intrabasinal faults exist, predominantly northeast-striking normal faults synthetic to the border fault system (e.g., Schlische, 1992). The Late Triassic basin sediments are subdivided based on lithostratigraphy into the predominantly fluvial Stockton Formation, predominantly deep-lake lacustrine Lockatong Formation, and predominantly red-bed lacustrine Passaic Formation (Figure 2) (Olsen et al., 1996). The three major formations are overlain by a series of thinner basalt flows interbedded with fluvio-lacustrine sedimentary formations of latest Triassic-Early Jurassic age, which are preserved in a relatively small northwestern area of the basin adjacent to the border fault (Figure 1c). The intrusive Palisade Sill occurs at different depths and stratigraphic levels at different locations. As the most recent seismic data by TriCarb illustrate (Figure 1d), the sill, at least in the northern part of the basin, forms a continuous body across the basin and is often discordant to bedding.

The coarse-grained Stockton Formation, which makes up the basal formation in the Newark Basin, has been identified as the primary target for $\mathrm{CO}_{2}$ storage (Collins, 2017). It consists of mostly buff and red conglomerate; buff, white, and gray arkose; and red

Table 1. Summary of reservoir and sealing properties of major Newark Basin formations.

Formation(s)

Favorable properties

CAMP basalt flows $\quad$ Reservoir-quality porosity $(\sim 15 \%)$ in the interflow zones.

Potential seals (massive basalt) in the flow interiors.

High reactivity with $\mathrm{CO}_{2}$ (mineral trapping).

Estimated $\mathrm{CO}_{2}$ storage capacity of similar units at the order of 1 gigaton (Goldberg et al., 2010).

\begin{tabular}{|l|l|}
\hline Passaic & $\begin{array}{l}\text { Numerous mudstone units with excellent sealing capacity. } \\
\text { Multiple reservoir targets in coarse-grained units with 10\%-18\% } \\
\text { porosity in the northern basin. }\end{array}$ \\
\hline Lockatong & Numerous mudstone units with excellent sealing capacity. \\
\hline Stockton & $\begin{array}{l}\text { Numerous mudstone units with excellent sealing capacity. } \\
\text { Multiple reservoir targets in abundant coarse-grained units with } \\
8 \%-18 \% \text { porosity. } \\
\text { Estimated } \mathrm{CO}_{2} \text { storage capacity of 2-30 gigatons (Collins, 2017). }\end{array}$ \\
\hline
\end{tabular}

Limited thickness of reservoir units.

Unknown lateral extend/continuity of reservoir units.

Potential fractures in sealing units.

Lateral heterogeneity.

Limited data on injectivity, potentially low permeability.

Possible proximity of basement faults.

Unknown injectivity.

Potential challenges

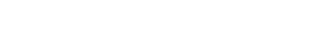


mudstone layers. In the central part of the basin, the Stockton Formation tends to fine upward, with the uppermost hundred or so meters dominated by red mudstone (Olsen et al., 1996). The Stockton Formation is largely fluvial (e.g., Smoot, 1991) and, consequently, is expected to have poor lateral correlation between individual units. However, a comparison of outcrop lithostratigraphy and the NBCP core (Princeton well) showed that its overall lithologic expression is consistent between the core and the type section at the Delaware River (Olsen et al., 1996). At the northeastern basin edge, lithologic expression of the Stockton Formation differs from the central locations in having thinner and laterally heterogeneous units dominated by buff arkosic sandstones and purple and red mudstones (Zakharova et al., 2016), much of which may be the lateral equivalent of the Lockatong Formation. The mudstone layers of the upper Stockton Formation, and the overlying Lockatong and Passaic formations, offer numerous levels of mudstone caprock for potential Stockton Formation reservoirs.

Full Stockton thickness is not well constrained throughout the basin as only two drill holes penetrated basement (Lamont test well 4 and North Central Oil J. Parestis no. 1 well), both of them located on the basin margins (Zakharova et al., 2016; Collins, 2017). Based on the structural constraints, the Stockton Formation is projected to reach approximately $1800 \mathrm{~m}$ thickness in the central portion of the basin, thinning toward the eastern basin margin (e.g., Schlische, 1992), and plausibly pinching out by onlap onto prerift rocks at the northeastern and southwestern ends of the basin (Olsen et al., 2016). Due to the northwestward dip, the depth to the top of the Stockton Formation varies significantly, from outcrops along the eastern basin margin to at least $5 \mathrm{~km}$ in some parts of the central basin (Schlische, 1992).

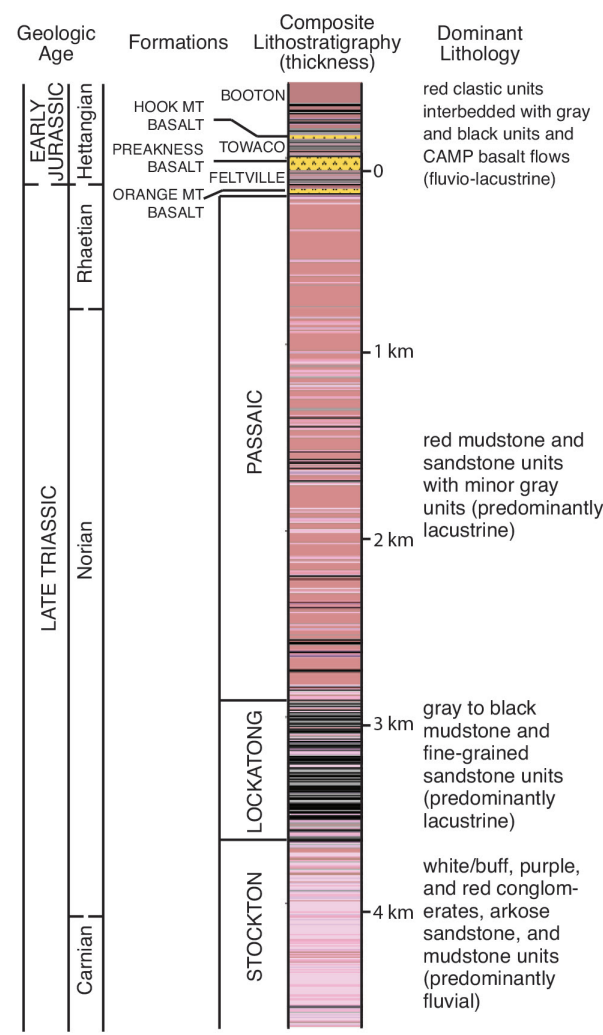

Figure 2. Simplified lithostratigraphy of the Newark Basin (adopted from Olsen et al., 1996 and Kent et al., 2017). The depth and thickness of lithologic units vary across the basin. The figure illustrates a composite lithostratigraphy of the drill cores from the NBCP (zero mark indicates top of the NBCP core), complemented by outcrop studies and short geotechnical cores for the Early Jurassic section. Yellow hue represents basalt flows of the CAMP.

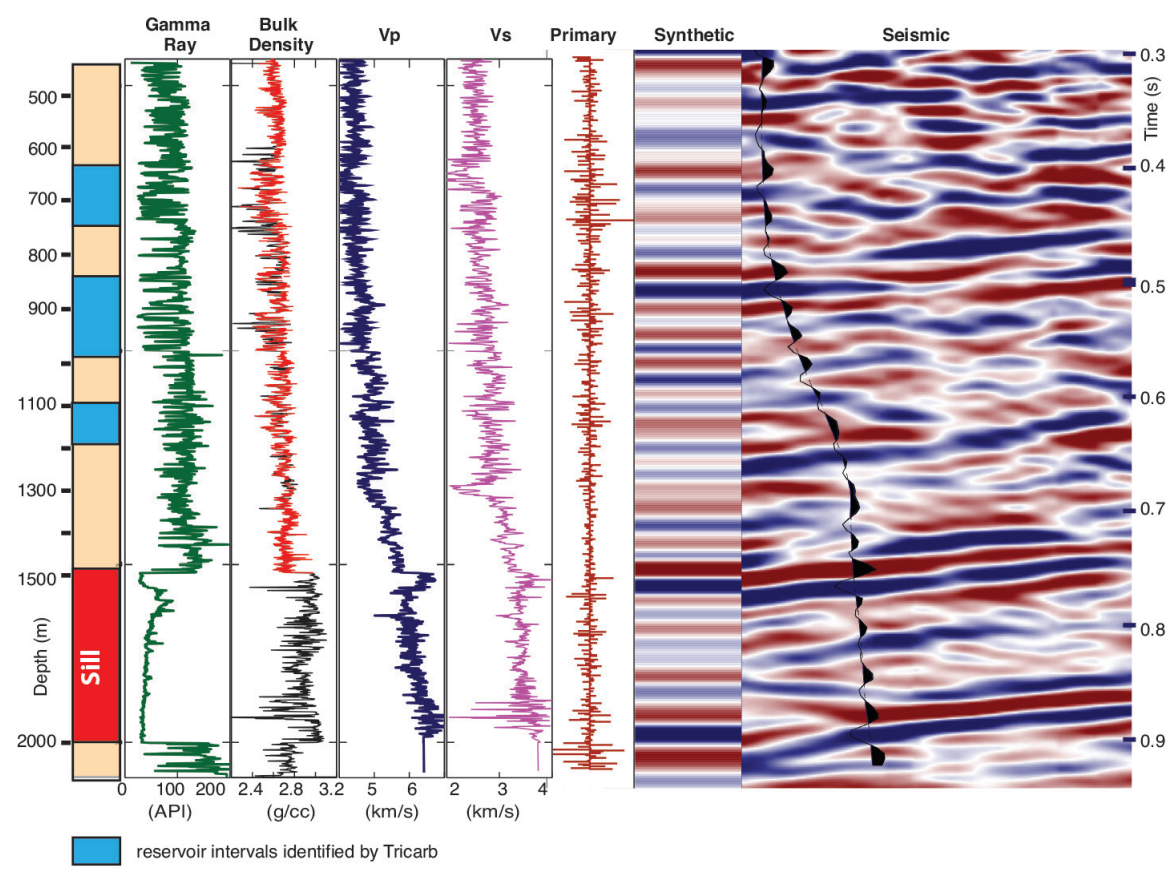

Figure 3. Geophysical data from the NYSTA Tandem Lot \# 1 well integrated with the TriCarb seismic data acquired in the northern Newark Basin. From left to right: simplified lithocolumn indicating potential reservoir intervals identified by TriCarb in blue; natural gamma ray activity log (green); bulk density log (raw data in black, corrected for borehole conditions in red); sonic P-wave velocity log (blue); sonic S-wave velocity log (magenta); reflection coefficient (primary) trace computed from the density and velocity logs; a section of synthetic seismogram computed from the primary trace; and a section of the reflection seismic data from Figure 1 with a synthetic trace overlain along the trajectory of Tandem Lot \# 1 well. As illustrated by the gamma log (low values in sandstones, high values in mudstones), sandstone layers at the locality are only $3-7 \mathrm{~m}$ thick and decrease in frequency with depth. 
Over more than two-thirds of the basin area, the Stockton Formation occurs at suitable sequestration depths (below about $800 \mathrm{~m}$, where $\mathrm{CO}_{2}$ is expected to be in supercritical state [Battelle, 2011]), but the upward migration along bedding toward the outcrops could be a concern.

The Lockatong and Passaic formations are largely lacustrine and cyclical, dominated by finer grain sizes (mudstone to fine sandstone) (Olsen, 1980; Olsen et al., 1996, 2016). The NBCP core holes in the central basin did not intersect any significant coarse sandstones in the Passaic Formation. Toward the basin edges, however, the Passaic becomes much coarser and includes a significant number of medium to coarse-grained sandstone and fine conglomerate layers (Olsen, 1980; Collins, 2017) (Figure 3). Intersected at shallow depths in the New York State Thruway Authority (NYSTA) Tandem Lot \#1 hole (Rockland County, New York), the layers are projected to occur at greater depths farther west, potentially suitable for supercritical $\mathrm{CO}_{2}$ storage. The reflection seismic profiles suggest some lateral continuity of Passaic Formation horizons in that part of the basin (Figure 1d), but the degree of lateral heterogeneity of the formation is unknown.

\section{Reservoir and sealing properties of sedimentary formations}

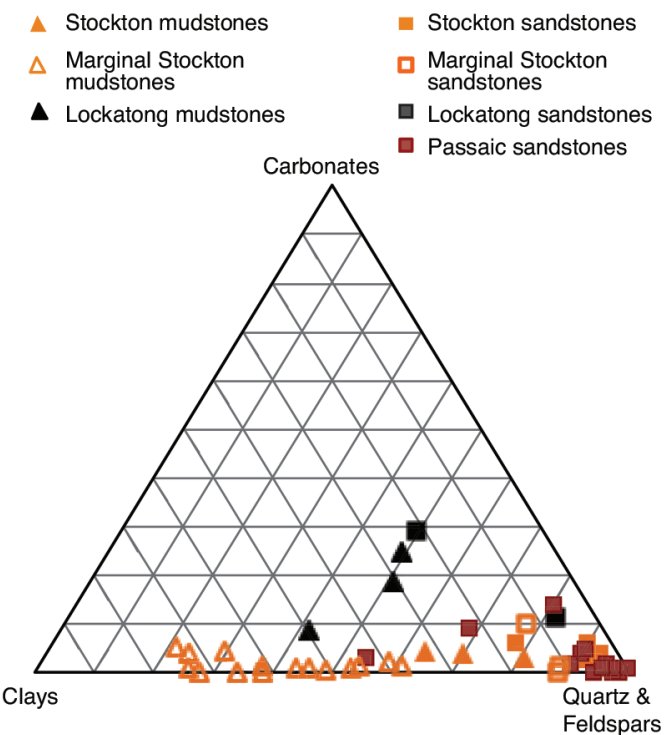

Figure 4. Representative compositions of the Newark Basin formations determined by $\mathrm{X}$-ray diffraction.
Stockton sandstones consist primarily of quartz and feldspars (Figure 4), with minor amounts of clays and calcite and occasionally mica, pyrite, and amphibole. The porosity is predominantly intergranular, although some porosity is also observed in leached and/ or weathered feldspars (Figure 5) (Collins, 2017). A compilation of more than 70 physical property measurements on core and borehole wall plugs from the NBCP Princeton well (central basin), NYSTA Tandem Lot \#1 well, and Lamont test well 4 (northern basin) shows that most of the Stockton Formation sandstones are characterized by a porosity from $8 \%$ to $18 \%$ and an air permeability between 0.1 and $50 \mathrm{mD}$ (Figure 6). Sampling for porosity analysis, however, was biased toward higher porosity intervals as potential reservoir targets, and a true porosity distribution for the Stockton is more likely to peak at lower values. Analysis of sonic porosity logs from the central basin (Princeton well) suggests that only about a quarter of the Stockton Formation thickness contains porosity over 6\% (Collins, 2017). Based on the available constraints on the Stockton Formation volume and effective porosity, TriCarb estimated potential $\mathrm{CO}_{2}$ storage capacity of this formation between 2 and 30 gigatonnes assuming the storage efficiency of $0.51 \%$ to $5.4 \%$, respectively (Collins, 2017). This equates to roughly 4 to 60 years' worth of $\mathrm{CO}_{2}$ emissions from New York, Pennsylvania, and New Jersey combined (EPA, 2019). These figures are likely overly optimistic as they do not consider injectivity of the Stockton Formation, only the nominal pore volume available for storage.

Hydraulic tests (Lamont test wells 3 and 4) in the marginal Stockton Formation, which is generally characterized by higher core porosity and permeability than in the central basin (Figure 6), showed little to no flow in most of the high-porosity sandstones, even at relatively shallow depths of 200-500 m below surface (Zakharova et al., 2016). In the same depth intervals where core data indicated high porosity and permeability in the arkosic sandstones, fluid flow was either zero or below the flowmeter detection limit ( $0.1 \mathrm{~L} / \mathrm{min}$ ) under ambient conditions (Yang et al., 2014; Zakharova et al., 2016). Under injection conditions, fluid flow could be detected only in a few sparse and narrow (1-3 m thick) intervals, ranging in transmissivity from $10^{-9}$ to $10^{-5} \mathrm{~m}^{2} / \mathrm{s}$. At least half of those transmissive intervals corresponded to fractures observed with a borehole televiewer (Zakharova et al., 2016). These observations suggest that core-scale properties are not representative of the field-scale formation properties, and larger scale heterogeneity appears to significantly reduce the reservoir quality compared to the sandstone matrix properties
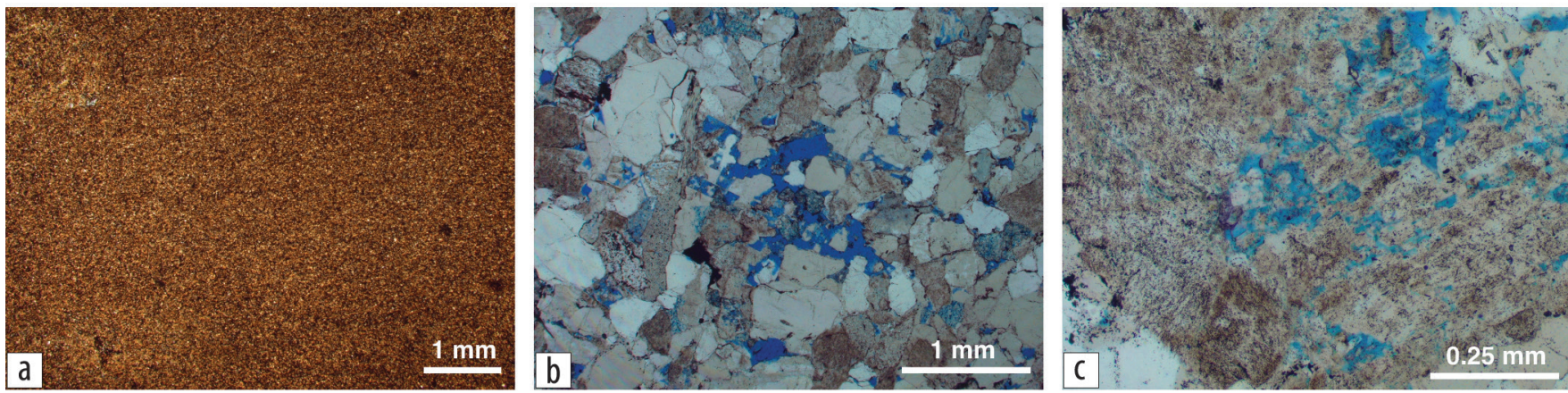

Figure 5. Thin-section images of representative samples from the Stockton Formation (Princeton well): (a) a red mudstone, (b) an arkosic sandstone with intergranular porosity, and (c) an arkosic sandstone with leached feldspars. Thin sections are mounted on blue epoxy to visually highlight pore spaces. 
measured on $5 \mathrm{~cm}$ long core plugs. Deeper parts of the Stockton Formation are likely to be more compacted with further reduction in porosity, as suggested by the overall lower porosity range of the Stockton Formation samples (NBCP, Princeton well, greater than $400 \mathrm{~m}$ depth) compared to the marginal Stockton samples (Lamont test well 4, less than $400 \mathrm{~m}$ depth) (Figure 6). In addition, deep samples from the Stockton display signs of hydrothermal alteration through sodium metasomatism, manifested as pervasive albite cement (El-Tabakh and Schreiber, 1998). Low hydraulic transmissivity of the Stockton Formation and its immediate proximity to crystalline basement raise a concern of pressure buildup and induced seismicity during $\mathrm{CO}_{2}$ injection, which is discussed in greater detail later.

A significant number of Passaic Formation sandstones from the northern part of the basin (NYSTA Tandem Lot \#1 well) are characterized by higher porosity and permeability values than the Stockton Formation - approximately $10 \%-18 \%$ porosity and air permeability up to $2000 \mathrm{mD}$ (Figure 6). Based on the sidewall core and well-log data, TriCarb identified three intervals with potential reservoir-quality sandstones at the location of NYSTA Tandem Lot \#1 well (Figure 3) (Collins, 2017). All of them have interbedded mudstone and siltstone layers, with a net volume of sandstones of $72 \%, 54 \%$, and $38 \%$ (listed in order of increasing depth). In the Tandem Lot hole, they occur at depths of 650-750, $850-1000$, and $1100-1300 \mathrm{~m}$, respectively (Figure 3). Only in the top of those three intervals do sandstones comprise more than two-thirds of the net thickness and form individual layers of more than a few meters thick. The bottom two intervals, with half or less thickness composed of sandstones, all less than $7 \mathrm{~m}$ thick, are arguably not of high reservoir quality. The Passaic Formation in the central basin is predominantly fine grained (Olsen et al., 1996), and the extent of porous Passaic sandstones in the north

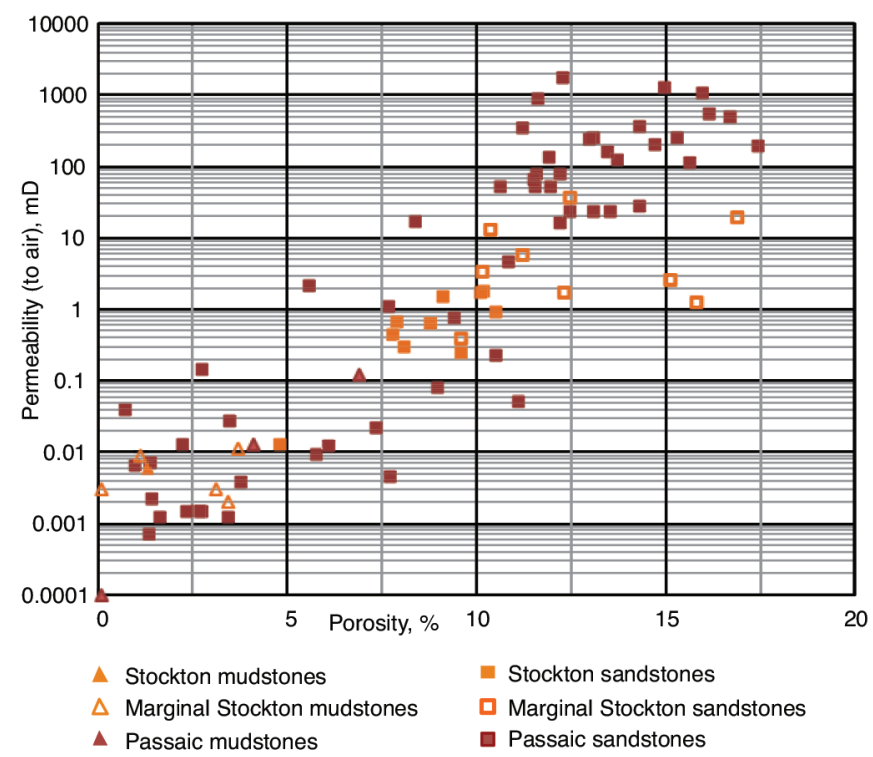

Figure 6. A compilation of core porosity and permeability data for the Newark Basin formations. Passaic sandstones with porosity under $5 \%$ came primarily from the Tandem Lot core, collected for depths below $1400 \mathrm{~m}$, while the rest of the samples were collected from drill core and sidewall plugs above $1100 \mathrm{~m}$. is unknown. Based on the outcrop dip and seismic data (Figure 1d), the sandstone layers intersected by the Tandem Lot well are projected to occur at greater depths to the west of the drilling site. However, there is a strong trend of porosity reduction with depths observed in the core and log data (Collins, 2017). For example, several conglomerate and sandstone beds, which were cored at about $1400 \mathrm{~m}$ depth in the Tandem Lot well, were fully cemented and had near zero porosity. Therefore, the extent of the shallow high-porosity Passaic Formation units cannot be reliably projected to greater depths in the basin.

Numerous layers of mudstones occur in all three of the major formations, offering multiple levels of potential caprock throughout the basin. A majority of tested mudstone samples have a low porosity (less than $5 \%$ ) and a low permeability (less than $0.1 \mathrm{mD}$ ) (Figure 6). Mercury injection capillary pressure indicates that pore throats in mudstones from all three formations are narrow - 0.001-0.03 microns (Figure 7). Calculated threshold $\mathrm{CO}_{2}$ column heights, which these mudstones could withstand, are on the order of several kilometers, suggesting excellent sealing capacity (Thibodeau et al., 2018). While the Newark Basin may lack the highest quality reservoir rocks, the lacustrine mudstones have good sealing properties for stratigraphic trapping of $\mathrm{CO}_{2}$ injected below. This suggests that other Mesozoic rift basins might be suitable for $\mathrm{CO}_{2}$ storage if proper reservoir layers could be identified.

\section{Role of fractures and geomechanical considerations}

An important attribute of the Newark Basin formations is the presence of widespread natural fractures, many of which are mineralized (e.g., Herman, 2009, 2010). The two dominant sets are extensional fractures steeply dipping to the southeast and bed-parallel fractures shallowly dipping generally to the northwest (e.g., Schlische, 1992; Goldberg et al., 2003; Matter et al., 2006; Herman, 2009). While fracture orientation in the basin is well described, their hydraulic properties are not well

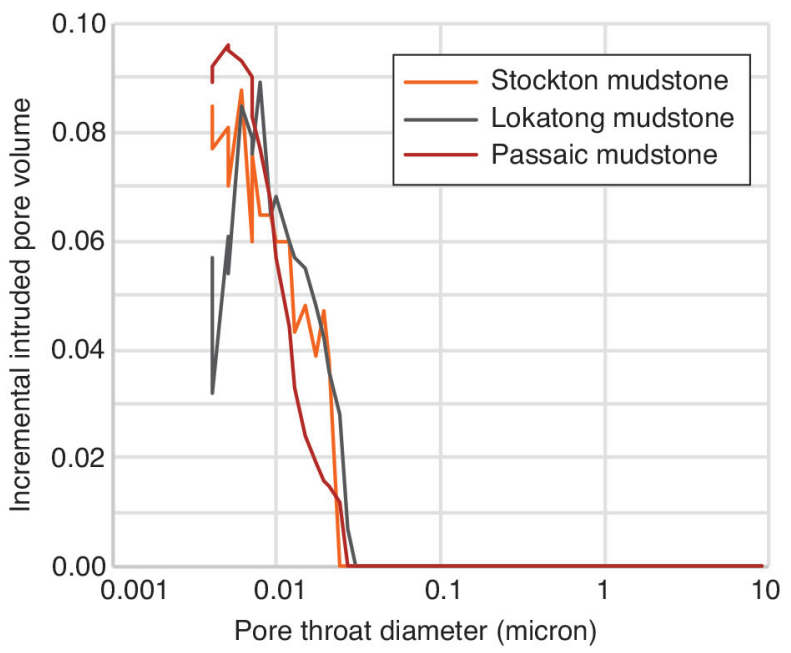

Figure 7. Representative pore-throat size distributions for the Newark Basin mudstones measured with mercury intrusion porosimetry. 
constrained, particularly below depths of a few hundred meters. Shallow aquifer systems in the Newark Basin (to about $200 \mathrm{~m}$ depth) are commonly associated with fractured sedimentary formations (Houghton, 1990; Morin et al., 1997, 2000; Lacombe and Burton, 2010; Heisig, 2011), but almost no data are available for depths below $200 \mathrm{~m}$. The flowmeter and injection test conducted in the marginal Stockton Formation sandstones in the 200-500 m depth range (Lamont test wells) demonstrated that most of the intersected fractures were not hydraulically conductive (Zakharova et al., 2016). The tests also suggested significantly inferior hydraulic properties below $200 \mathrm{~m}$ than in the shallow fractured aquifers. For example, water wells penetrating the shallow Stockton Formation in the central basin have water supply rates up to $10 \mathrm{~L} / \mathrm{s}$ (e.g., Herman, 2010), but water flow rates in the marginal Stockton Formation are about two orders of magnitude lower (Yang et al., 2014; O'Mullan et al., 2015). The lower transmissivities observed in the marginal Stockton can be explained by increased overburden pressure at greater depths, closing fractures, and reducing bulk conductivity, as well as by its closer proximity to the basin edge where the Stockton Formation grades laterally into the Lockatong Formation, which exhibits inferior hydraulic properties basin wide (Herman, 2010). Therefore, data in the marginal Stockton Formation might not be directly applicable to characterizing hydraulic properties in the central Stockton Formation, and no data on fracture transmissivity are available for the Stockton Formation below depths of a few hundred meters.

A major concern regarding $\mathrm{CO}_{2}$ injection into fractured and faulted rocks of the central Newark Basin would be a risk of induced seismicity (Zoback and Gorelick, 2012). More than 300 seismic events up to magnitude 5.25 have been identified from historical records and instrumental data in the crystalline rocks around the Newark Basin and in the Ramapo seismic zone that is associated with its border fault system (Goldberg et al., 2003; Sykes et al., 2008). Since induced seismicity from fluid injections in sedimentary basins has often been associated with basement faults (e.g., Keranen et al., 2014; Yeck et al., 2016), pressurized injection into the Stockton Formation immediately above basement could raise a concern of potential fault reactivation. Borehole breakouts observed in multiple boreholes in the Newark Basin confirm present-day strike-slip/reversefaulting stress regime with a northeast-southwest direction of the maximum compressive stress and are consistent with regional tectonic data (Goldberg et al., 2003; Sykes et al., 2008; Zakharova and Goldberg, 2014). Modeling of borehole breakouts using formation strength from core measurements suggests that horizontal stress magnitudes in the Newark Basin could be near the frictional failure limit for the strike-slip and reversefaulting regimes. Many of the observed fractures striking northeast-southwest would be prone to activation in the strikeslip regime with a minor increase in pore pressure, although assessing the likelihood and maximum magnitude of such events is not feasible with currently available data. Hydrologic numerical modeling for the Newark Basin formations showed that an industrial-scale sequestration project (injection of $1 \mathrm{MMt} / \mathrm{yr}$ over 30 years) would result in a maximum pore pressure rise of approximately $8 \mathrm{MPa}$ for a base-case formation permeability of $50 \mathrm{mD}$ (Collins, 2017). Such a pressure buildup, even if short in duration, could exceed triggering threshold for favorably oriented fractures and faults in the basin. Therefore, the currently available data on the state of stress and formation properties in the Newark Basin suggest a potential risk of induced seismicity during an industrial-scale $\mathrm{CO}_{2}$ injection, but quantifying the risks and possible magnitudes of induced events requires additional data and geomechanical analysis.

\section{Potential for storage in igneous rocks}

Numerous onshore and offshore Mesozoic rift basins along the Atlantic coast host remnants of the CAMP, which may have been the most extensive large igneous province (LIP) at the time of its emplacement about 200 Myr ago (Marzoli et al., 1999). CAMP Basalt flows, as in other LIPs, tend to be laterally extensive (from several to hundreds of square kilometers), hundreds of meters thick, and have highly vesicular flow boundaries (Puffer and Philpotts, 1988; Olsen et al., 2007). Such interflow zone properties in basalts, when well sealed, could be effective as $\mathrm{CO}_{2}$ reservoirs (e.g., McGrail et al., 2006). In particular, the lowest CAMP Basalt unit, the Orange Mountain Basalt, cored during the NBCP (Martinsville site), contains interflow zones with estimated porosity of $15 \%$ (Goldberg et al., 2010), but it occurs at shallow depths (less than $1 \mathrm{~km}$ ) over most of its area. Such basaltic flows are found deeper in other Mesozoic rift basins such as the Hartford Basin where postbasalt strata reach thickness in excess of $2 \mathrm{~km}$ (e.g., Kent and Olsen, 2008; Akintunde et al., 2013). Goldberg et al. (2010) estimate that basalt storage capacity of even a small rift basin, such as the Sandy Hook Basin offshore New Jersey, may exceed hundreds of megatons of $\mathrm{CO}_{2}$. The main advantage of targeting basaltic rocks for carbon sequestration is their potential for mineral carbonation, which transforms mobile $\mathrm{CO}_{2}$ into a stable mineral form (e.g., McGrail et al., 2006; Matter et al., 2016). Schaef et al. (2010) tested the $\mathrm{CO}_{2}$ reactivity of various flood basalts and showed that a sample from the Holyoke Basalt of the Hartford Basin*, equivalent of the second flow of the Preakness Basalt, was by far the most reactive with supercritical $\mathrm{CO}_{2}$. This flow and its untested Newark Basin equivalent (Preakness Basalt) have a distinctive and dense fracture system (Olsen et al., 2016). Extrusive flows in the Newark Basin and other Mesozoic rift basins, therefore, present attractive targets for $\mathrm{CO}_{2}$ sequestration.

The Palisade Sill, which is also characterized by mafic composition (primarily dolerite, or diabase) and forms an extensive and continuous body (Figures $1 \mathrm{c}$ and $1 \mathrm{~d}$ ), does not appear to possess enough porosity to be considered as a potential $\mathrm{CO}_{2}$ reservoir. The sill displays many cooling joints and fractures, but they all appear either mineralized or closed at depth (Goldberg and Burgdorff, 2005; Matter et al., 2006; Zakharova et al., 2016). Such impervious sills and dykes could serve as caprock, providing

*It is labeled "Newark Basin" in the paper, but the locality is identified as "... a roadside outcrop near Branford, Connecticut ..." (p. 250), which is in the Hartford Basin, and a location where the second flow of the Holyoke Basalt is the only well-exposed unit. 
both structural and mineral trapping for underlying $\mathrm{CO}_{2}$ reservoirs in Mesozoic rift basins (Akintunde et al., 2013).

\section{Conclusions}

Extensive coarse-grained arkosic sandstones occur in the Stockton Formation and more locally in the Passaic Formation in the Newark rift basin. Routine core measurements in these sandstones suggest reservoir-quality porosity and permeability, but limited borehole tests indicate relatively poor hydraulic properties. These results highlight the importance of the scale of investigation when determining hydraulic properties in heterogeneous rift basin formations. The core samples were taken from coarse-grained intervals devoid of fractures and visible heterogeneities and therefore represent centimeter-scale matrix porosity of select sandstone layers. The borehole hydraulic tests characterize formation properties at a scale of meters to tens of meters, representing a combined effect of matrix property, fractures, and various formation heterogeneities. Since in situ measurements indicate much lower formation permeability than laboratory matrix properties, formation heterogeneities appear to decrease the net effective hydraulic conductivity in these sandstones. A low in situ permeability raises a concern of pore pressure buildup during a large-volume $\mathrm{CO}_{2}$ injection, potentially inducing slip on fractures and faults, which are common across the basin. The state of stress inferred from borehole data suggests high compressive stresses and a risk of fracture reactivation with only a few MPa pore pressure increase. This risk renders the basal Stockton Formation (overlying basement at many locations) a less attractive target for industrial $\mathrm{CO}_{2}$ storage than the shallower Passaic Formation. High-porosity samples were collected from very shallow depths in the Passaic, and the extent of high-porosity zones to greater depths could not be confirmed. Alternatively, CAMP Basalt flows occurring in the Newark Basin and similar Mesozoic rift basins, both onshore and offshore of the U.S. Atlantic coast, present an attractive target for $\mathrm{CO}_{2}$ storage due to high $\mathrm{CO}_{2}$ reactivity and high porosity along flow boundaries. If injectivity of such flow boundaries is confirmed, their large lateral extent and numerous occurrences would offer ample reservoir capacity with overlying lacustrine mudstones serving as caprock. Overall, available data on the Newark Basin Formation properties suggest a limited capacity for $\mathrm{CO}_{2}$ storage due to potentially low injectivity in deeper reservoirs and a potential risk of induced seismicity on reactivated faults. Other Mesozoic rift basins, both onshore and offshore, with more favorable stress conditions and architecture but similarly containing thick, high-porosity sandstones, basaltic interflow zones, and overlying mudstone and basalt sealing layers, should be investigated as viable resources for large-scale $\mathrm{CO}_{2}$ storage. ITL

\section{Acknowledgments}

A large portion of the material presented in this paper is based upon work by TriCarb Consortium for Carbon Sequestration, supported by the Department of Energy (National Energy Technology Laboratory) under award number DE-FE0002352. The Newark Basin Coring Project was supported by the National Science Foundation (grant no. EAR 89-16726 and EAR 90-17785).

\section{Data and materials availability}

Data associated with this research are available and can be obtained by contacting the corresponding author.

Corresponding author: n.zakh@cmich.edu

\section{References}

Akintunde, O. M., C. Knapp, and J. Knapp, 2013, Petrophysical characterization of the South Georgia rift basin for supercritical $\mathrm{CO}_{2}$ storage: A preliminary assessment: Environmental Earth Sciences, 70, no. 7, 2971-2985, https://doi.org/10.1007/ s12665-013-2355-6.

Aydin, G., I. Karakurt, and K. Aydiner, 2010, Evaluation of geologic storage options of $\mathrm{CO}_{2}$ : Applicability, cost, storage capacity and safety: Energy Policy, 38, no. 9, 5072-5080, https://doi.org/10.1016/j. enpol.2010.04.035.

Battelle, 2011, Preliminary characterization of $\mathrm{CO}_{2}$ sequestration potential in New Jersey and the offshore coastal region: Midwest Regional Carbon Sequestration Partnership Final Report, DOENETL Cooperative Agreement DE-FC26-05NT42589.

Collins, D. J., 2017, Characterization of the Triassic Newark Basin of New York and New Jersey for geologic storage of carbon dioxide: U.S. Department of Energy Office of Fossil Energy, https://doi. org/10.2172/1368193.

El-Tabakh, M., and B. Schreiber, 1998, Diagenesis of the Newark rift basin, eastern North America: Sedimentology, 45, no. 5, 855-874, https://doi.org/10.1046/j.1365-3091.1998.00183.x.

EPA, 2019, Inventory of U.S. greenhouse gas emissions and sinks: 1990-2017: U.S. Environmental Protection Agency, https://www. epa.gov/ghgemissions/inventory-us-greenhouse-gas-emissionsand-sinks-1990-2017, accessed 2 December 2019.

Goldberg, D. S., and K. Burgdorff, 2005, Natural fracturing and petrophysical properties of the Palisades dolerite sill: Geological Society of London, Special Publications, 240, no. 1, 25-36, https:// doi.org/10.1144/GSL.SP.2005.240.01.03.

Goldberg, D. S., D. V. Kent, and P. E. Olsen, 2010, Potential on-shore and off-shore reservoirs for $\mathrm{CO}_{2}$ sequestration in Central Atlantic magmatic province basalts: Proceedings of the National Academy of Sciences, 107, no. 4, 1327-1332, https:// doi.org/10.1073/pnas.0913721107.

Goldberg, D., T. Lupo, M. Caputi, C. Barton, and L. Seeber, 2003, Stress regimes in the Newark Basin rift: Evidence from core and downhole data, in P. M. LeTourneau and P. E. Olsen, eds., The great rift valleys of Pangea in eastern North America: Columbia University Press, 104-117, https://doi.org/10.7312/leto11162.

Goldberg, D. S., D. Reynolds, C. Williams, W. K. Witte, P. E. Olsen, and D. V. Kent, 1994, Well logging results from the Newark Rift Basin Coring Project: Scientific Drilling, 4, 267-279.

Heisig, P. M., 2011, Water resources of Rockland County, New York, 2005-07, with emphasis on the Newark Basin bedrock aquifer: U.S. Geological Survey, Scientific Investigations Report 2010-5245, https://doi.org/10.3133/sir20105245.

Herman, G. C., 2009, Steeply-dipping extension fractures in the Newark Basin, New Jersey: Journal of Structural Geology, 31, no. 9, 996-1011, https://doi.org/10.1016/j.jsg.2008.10.008.

Herman, G. C., 2010, Hydrogeology and borehole geophysics of fractured-bedrock aquifers, in G. C. Herman and M. E. Serfes, eds., Contributions to the geology and hydrogeology of the Newark Basin: New Jersey Geological Survey Bulletin, 77, F1-F45. 
Houghton, H. F., 1990, Hydrogeology of the Early Mesozoic rocks of the Newark Basin, New Jersey: Proceedings of the $7^{\text {th }}$ Annual Meeting of the Geological Association of New Jersey, E1-E36.

IEA, 2018, World energy outlook 2018: International Energy Agency, https:/www.iea.org/reports/world-energy-outlook-2018, accessed 8 December 2019.

IPCC, 2018, Global warming of $1.5^{\circ} \mathrm{C}$ : IPCC Special Report, https:// www.ipcc.ch/sr15/, accessed 8 December 2019.

Kent, D. V., and P. E. Olsen, 2008, Early Jurassic magnetostratigraphy and paleolatitudes from the Hartford continental rift basin (eastern North America): Testing for polarity bias and abrupt polar wander in association with the Central Atlantic magmatic province: Journal of Geophysical Research. Solid Earth, 113, no. B6, https:// doi.org/10.1029/2007JB005407.

Kent, D. V.,P.E. Olsen, and G. Muttoni, 2017, Astrochronostratigraphic polarity time scale (APTS) for the Late Triassic and Early Jurassic from continental sediments and correlation with standard marine stages: Earth-Science Reviews, 166, 153-180, https://doi. org/10.1016/j.earscirev.2016.12.014.

Kent, D. V., P. E. Olsen, and W. K. Witte, 1995, Late Triassic-earliest Jurassic geomagnetic polarity sequence and paleolatitudes from drill cores in the Newark rift basin, eastern North America: Journal of Geophysical Research, 100, no. B8, 14965-14998, https://doi.org/10.1029/95JB01054.

Keranen, K. M., M. Weingarten, G. A. Abers, B. A. Bekins, and S. Ge, 2014, Sharp increase in central Oklahoma seismicity since 2008 induced by massive wastewater injection: Science, $\mathbf{3 4 5}$, no. 6195, 448-451, https://doi.org/10.1126/science.1255802.

Lacombe, P. J., and W. C. Burton, 2010, Hydrogeologic framework of fractured sedimentary rock, Newark Basin, New Jersey: Groundwater Monitoring and Remediation, 30, no. 2, 35-45, https://doi.org/10.1111/j.1745-6592.2010.01275.x.

Levine, J. S., I. Fukai, D. J. Soeder, G. Bromhal, R. M. Dilmore, G. D. Guthrie, T. Rodosta, et al., 2016, US DOE NETL methodology for estimating the prospective $\mathrm{CO}_{2}$ storage resource of shales at the national and regional scale: International Journal of Greenhouse Gas Control, 51, 81-94, https://oi.org/10.1016/j. ijggc.2016.04.028.

Marzoli, A., P. R. Renne, E. M. Piccirillo, M. Ernesto, G. Bellieni, and A. De Min, 1999, Extensive 200-million-year-old continental flood basalts of the Central Atlantic Magmatic Province: Science, 284, no. 5414, 616-618, https://doi.org/10.1126/ science.284.5414.616.

Matter, J. M., D. S. Goldberg, R. Morin, and M. Stute, 2006, Contact zone permeability at intrusion boundaries: New results from hydraulic testing and geophysical logging in the Newark rift basin, New York, USA: Hydrogeology Journal, 14, no. 5, 689-699, https://doi.org/10.1007/s10040-005-0456-3.

Matter, J. M., M. Stute, S. Ó. Snæbjörnsdottir, E. H. Oelkers, S. R. Gislason, E. S. Aradottir, B. Sigfusson, et al., 2016, Rapid carbon mineralization for permanent disposal of anthropogenic carbon dioxide emissions: Science, 352, no. 6291, 1312-1314, https://doi.org/10.1126/science.aad8132.

McGrail, B. P., H. T. Schaef, A. M. Ho, Y. J. Chien, J. J. Dooley, and C. L. Davidson, 2006, Potential for carbon dioxide sequestration in flood basalts: Journal of Geophysical Research: Solid Earth, 111, no. B12, https://doi.org/10.1029/2005JB004169.

McGrail, B. P., H. T. Schaef, F. A. Spane, J. B. Cliff, O. Qafoku, J. A. Horner, C. J. Thompson, A. T. Owen, and C. E. Sullivan, 2016, Field validation of supercritical $\mathrm{CO}_{2}$ reactivity with basalts: Environmental Science \& Technology Letters, 4, no. 1, 6-10, https://doi.org/10.1021/acs.estlett.6b00387.
Morin, R. H., G. B. Carleton, and S. Poirier, 1997, Fractured-aquifer hydrogeology from geophysical logs: The Passaic Formation, New Jersey: Ground Water, 35, no. 2, 328-338, https://doi. org/10.1111/j.1745-6584.1997.tb00090.x.

Morin, R. H., L. A. Senior, and E. R. Decker, 2000, Fractured-aquifer hydrogeology from geophysical logs: Brunswick Group and Lockatong Formation, Pennsylvania: Ground Water, 38, no. 2, 182-192, https://doi.org/10.1111/j.1745-6584.2000.tb00329.x.

Olsen, P. E., 1980, The latest Triassic and Early Jurassic formations of the Newark Basin (eastern North America, Newark Supergroup): Stratigraphy, structure, and correlation: New Jersey Academy of Science Bulletin, 25, 25-51.

Olsen, P. E., P. J. Gore, and R. W. Schische, 1989, Tectonic, depositional, and paleoecological history of Early Mesozoic rift basins, eastern North America: International Geological Congress, Field Trip Guidebook, no. T351.

Olsen, P. E., D. V. Kent, B. Cornet, W. K. Witte, and R. W. Schlische, 1996, High-resolution stratigraphy of the Newark rift basin (early Mesozoic, eastern North America): GSA Bulletin, 108, no. 1, 40-77, https://doi.org/10.1130/0016-7606(1996)108<0040:HRS $\mathrm{OTN}>2.3 . \mathrm{CO} ; 2$.

Olsen, P. E., S. T. Kinney, N. V. Zakharova, R. W. Schlische, M. O. Withjack, D. V. Kent, D. S. Goldberg, and B. E. Slater, 2016, New insights on rift basin development and the geological carbon cycle, mass extinction, and carbon sequestration from outcrops and new core, drill holes, and seismic lines from the northern Newark Basin (New York and New Jersey), in A. E. Gates, ed., $88^{\text {th }}$ Annual New York State Geological Field Conference Guidebook, 190-274.

Olsen, P. E., J. P. Smoot, and P. LeTourneau, 2007, Field guide to Earth's largest continental flood basalt province, the CAMP, as expressed in the Culpeper Basin, VA: Fieldtrip guide for the $11^{\text {th }}$ Annual Continental Scientific Drilling Workshop: 1-45.

O’Mullan, G., M. E. Dueker, K. Clauson, Q. Yang, K. Umemoto, N. Zakharova, J. Matter, M. Stute, T. Takahashi, and D. Goldberg, 2015, Microbial stimulation and succession following a test well injection simulating $\mathrm{CO}_{2}$ leakage into a shallow Newark basin aquifer: PLoS One, 10, no. 1, e0117812, https://doi.org/10.1371/ journal.pone. 0117812 .

Pogge von Strandmann, P. A. E., K. W. Burton, S. O. Snæbjörnsdóttir, B. Sigfússon, E. S. Aradóttir, I. Gunnarsson, H. A. Alfredsson, K. G. Mesfin, E. H. Oelkers, and S. R. Gislason, 2019, Rapid $\mathrm{CO}_{2}$ mineralization into calcite at the CarbFix storage site quantified using calcium isotopes: Nature Communications, 10, no. 1, https://doi.org/10.1038/s41467-019-10003-8.

Puffer, J. H., and A. R. Philpotts, 1988, Eastern North American quartz tholeiites: Geochemistry and petrology: Developments in Geotectonics, 22, 579-605, https://doi.org/10.1016/ B978-0-444-42903-2.50029-4.

Rodosta, T., W. Aljoe, G. Bromhal, and D. Damiani, 2017, US DOE Regional Carbon Sequestration Partnership Initiative: New insights and lessons learned: Energy Procedia, 114, 5580-5592, https://doi.org/10.1016/j.egypro.2017.03.1698.

Schaef, H. T., B. P. McGrail, and A. T. Owen, 2010, Carbonate mineralization of volcanic province basalts: International Journal of Greenhouse Gas Control, 4, no. 2, 249-261, https://doi. org/10.1016/j.ijggc.2009.10.009.

Schlische, R. W., 1992, Structural and stratigraphic development of the Newark extensional basin, eastern North America: Evidence for the growth of the basin and its bounding structures: Geological Society of America Bulletin, 104, no. 10, 1246-1263, https://doi. org/10.1130/0016-7606(1992)104<1246:SASDOT>2.3.CO;2.

Jaindary $20 Z U$ 
Smoot, J. P., 1991, Sedimentary facies and depositional environments of early Mesozoic Newark Supergroup basins, eastern North America: Palaeogeography, Palaeoclimatology, Palaeoecology, 84, no. 1-4, 369-423, https://doi.org/10.1016/0031-0182(91)90055-V.

Sykes, L. R., J. G. Armbruster, W.-Y. Kim, and L. Seeber, 2008, Observations and tectonic setting of historic and instrumentally located earthquakes in the greater New York City-Philadelphia area: Bulletin of the Seismological Society of America, 98, no. 4, 1696-1719, https://doi.org/10.1785/0120070167.

Thibodeau, C. L., N. V. Zakharova, and D. S. Goldberg, 2018, $\mathrm{CO}_{2}$ sealing capacity of the Newark Basin rift mudstones: Presented at 2018 Fall Meeting, AGU, MR53A-0093.

Withjack, M. O., R. W. Schlische, M. L. Malinconico, and P. E. Olsen, 2013, Rift-basin development: Lessons from the TriassicJurassic Newark Basin of eastern North America: Geological Society of London, Special Publications, 369, no. 1, 301-321, https://doi.org/10.1144/SP369.13.

Yang, Q., J. Matter, M. Stute, T. Takahashi, G. O’Mullan, K. Umemoto, K. Clauson, et al., 2014, Groundwater hydrogeochemistry in injection experiments simulating $\mathrm{CO}_{2}$ leakage from geological storage reservoir: International Journal of Greenhouse
Gas Control, 26, 193-203, https://doi.org/10.1016/j. ijggc.2014.04.025.

Yeck, W. L., M. Weingarten, H. M. Benz, D. E. McNamara, E. A. Bergman, R. B. Herrmann, J. L. Rubinstein, and P. S. Earle, 2016, Far-field pressurization likely caused one of the largest injection induced earthquakes by reactivating a large preexisting basement fault structure: Geophysical Research Letters, 43, no. 19, 10198-10207, https://doi.org/10.1002/2016GL070861.

Zakharova, N. V., and D. S. Goldberg, 2014, In situ stress analysis in the northern Newark Basin: Implications for induced seismicity from $\mathrm{CO}_{2}$ injection: Journal of Geophysical Research: Solid Earth, 119, no. 3, 2362-2374, https://doi.org/10.1002/2013JB010492.

Zakharova, N. V., D. S. Goldberg, P. E. Olsen, D. V. Kent, S. Morgan, Q. Yang, M. Stute, and J. M. Matter, 2016, New insights into lithology and hydrogeology of the northern Newark rift basin: Geochemistry Geophysics Geosystems, 17, no. 6, 2070-2094, https://doi.org/10.1002/2015GC006240.

Zoback, M. D., and S. M. Gorelick, 2012, Earthquake triggering and large-scale geologic storage of carbon dioxide: Proceedings of the National Academy of Sciences, 109, no. 26, 10164-10168, https://doi.org/10.1073/pnas.1202473109. 